\title{
Analisis Faktor-Faktor yang Mempengaruhi Korupsi pada Pemerintah Daerah di Jawa Tengah Menggunakan Teori Fraud Triangle
}

\author{
Gilang Satryo Wicaksono ${ }^{1}$, Tri Jatmiko Wahyu Prabowo ${ }^{2}$ \\ Universitas Diponegoro,Indonesia \\ gilangsatryowicaksono@mail.com, trijatmikoprabowo@lecturer.undip.ac.id
}

*Penulis Korespondensi

Diajukan : 25 Januari 2022

Disetujui : 1 Februari 2022

Dipublikasi : 2 Februari 2022

\begin{abstract}
Cases of corruption that occur are increasing in Indonesia from year to year, including in local government. Various efforts have been made to prevent corruption, but there are still many cases of corruption in local governments in Central Java. The fraud triangle theory is used to find out the causes of corruption, which consist of pressure, opportunity, and rationalization. This study aims to analyze the factors causing corruption in local governments in Central Java using the fraud triangle theory which is proxied using the variables of regional financial performance, regional income, regional capital expenditures, internal audit capabilities, audit opinions, and regional personnel expenditures. This study uses quantitative methods and purposive sampling method using secondary data. The sample in this study is the district/city level local government in Central Java Province for the 2015 - 2019 period, which has a corruption case and has been decided by a firstlevel court, has been audited by the BPK, has an APIP Capability assessment, and has complete LKPD. The method of data analysis in this study used SPSS with logistic regression method. The results of this study indicate that regional financial performance, regional income, and internal audit capabilities have no effect on corruption, regional capital expenditures and regional personnel expenditures have a significant positive effect on corruption, and audit opinion has a significant negative effect on corruption.
\end{abstract}

Keywords: Corruption, Fraud Triangle, Regional Financial Performance, Regional Income, Central Java

\section{PENDAHULUAN}

Fraud dapat ditemukan di area swasta dan publik. Istilah fraud dicirikan sebagai pemerasan atau penipuan di bidang moneter. Fraud dapat dilakukan dari internal maupun eksternal dalam suatu organisasi untuk meraup keuntungan terhadap diri sendiri atau kelompok yang berakibat kerugian terhadap lain pihak (ACFE, 2016). Berdasarkan riset yang dilakukan oleh ACFE Indonesia, pada tahun 2019 total kerugian akibat fraud mencapai Rp. 873.430.000.000 dengan kasus fraud sebanyak 239 kasus. Korupsi adalah salah satu jenis dari fraud yang paling tinggi dilakukan berupa persentase $64,4 \%$, disusul oleh penyalahgunaan aset dengan persentase $28,9 \%$ dan fraudulent statement $6,7 \%$ (ACFE Indonesia, 2020)

Korupsi adalah tindakan yang destruktif dan masih terjadi di Indonesia. Banyak faktor yang mempengaruhi terjadinya korupsi, Salah satunya lemahnya pengawasan pada belanja modal daerah bisa menjadi salah satu factor. Adanya intervensi dari pihak lain seperti pengusaha atau vendor kepada kepala daerah atau pejabat terkait agar tender dimenangkan oleh pengusaha tersebut kemudian harga barang/jasa dinaikkan dan selisihnya dibagi-bagikan, menjadi salah satu celah terjadinya korupsi yang terjadi di badan pemerintah yang melakukan penganggaran.

Lemahnya pengawasan dan kurangnya kepuasan pegawai pemerintahan akan gajinya juga menjadi faktor penyebab korupsi. Lembaga yang paling terdampak adalah instansi pemerintah, baik 
di pusat maupun di daerah akibat korupsi yang dilakukan oleh pegawai pemerintah. Provinsi Jawa Tengah sendiri berada pada urutan dua dalam hal banyaknya penindakan kasus korupsi berdasarkan Provinsi yaitu sebanyak 30 kasus, satu tingkat dibawah Provinsi Jawa Timur dengan banyaknya kasus 42. Sebagai upaya pencegahan korupsi, pemerintah telah menetapkan peraturan dan membentuk berbagai lembaga yang bertugas untuk mencegah, mengawasi, dan menindak terjadinya korupsi di pemerintahan untuk melindungi aset negara.

Banyak teori yang dikembangkan untuk mencegah terjadinya korupsi, salah satunya yaitu fraud triangle. Teori ini menyatakan fraud dapat terjadi oleh tiga faktor, yaitu tekanan, peluang, dan rasionalisasi. Beberapa penelitian menggunakan teori fraud triangle untuk mengetahui faktor apa saja yang menyebabkan terjadi korupsi diberbagai sektor berdasarkan rasio keuangan dan penilaian terhadap kinerja pemerintah daerah. Selain itu, beberapa penelitian menggunakan metode riset melalui kuesioner guna menemukan dan mengetahui kaitannya terhadap faktor yang menyebabkan tindakan korupsi berdasarkan persepsi pegawai. Tetapi kelemahan dari metode tersebut adalah bisa saja jawaban dari responden tidak mencerminkan keadaan yang sebenarnya. Dari beberapa penelitian, diketemukan perbedaan proksi yang dipergunakan guna pengukuran variabel dan hasil penelitian mengenai faktor yang menyebabkan terjadinya korupsi dengan menggunakan teori fraud triangle. Karena kinerja pemerintah tidak bisa diukur sama dengan cara mengukur kinerja swasta.

Penelitian dari Maria \& Gudono (2017) menggunakan rasio-rasio keuangan untuk mengukur faktor-faktor yang menyebabkan terjadinya korupsi di pemerintahan daerah, yaitu dengan menggunakan variabel efisiensi keuangan daerah, Kinerja Keuangan Daerah, solvabilitas keuangan, dan kemandirian daerah.

Selain itu, penelitian yang menggunakan penilaian yang telah dilakukan pemerintah untuk mengukur faktor yang menyebabkan korupsi di pemerintah daerah dan karakteristik daerah masingmasing, seperti penelitian Muhtar, Sutaryo, \& Sriyanto (2018) yang menggunakan variabel akuntabilitas kinerja, kemampuan audit internal, dan belanja pegawai daerah, Isnadiva dan Haryanto (2021) yang menggunakan variabel opini audit, dan Maria et al (2019) yang menggunakan kompleksitas daerah dan ukuran daerah.

Peneliti mencoba untuk menemukan dan mengetahui kaitannya faktor yang mengakibatkan korupsi berdasarkan rasio-rasio keuangan dari kegiatan yang telah dilaksanakan oleh pemerintah daerah dan penilaian yang telah dilakukan oleh pemerintah terhadap pemerintah daerah. Atas dasar uraian yang telah peneliti sampaikan pada pembahasan sebelumnya, peneliti tertarik untuk meneliti berkaitan dengan judul "Analisa Faktor-Faktor yang Mempengaruhi Korupsi pada Pemerintah Daerah di Jawa Tengah Menggunakan Teori Fraud Triangle".

\section{Teori Fraud Triangle}

\section{STUDI LITERATUR}

Fraud triangle memberikan sebuah kerangka yang berguna bagi organisasi atau perusahaan untuk menganalisa kerentanan atau kekurangan organisasi terhadap fraud. Teori ini menunjukkan bahwa seseorang akan melakukan fraud saat ada permasalahan keuangan yang tidak dapat diselesaikan secara bersama sama (tekanan), yakin dan tahu bahwa masalah itu bisa diselesaikan dengan cara tersembunyi menggunakan pekerjaan atau jabatan yang dimilikinya (peluang), dan merubah pemikiran dari konsep orang yang diberi tanggung jawab untuk memegang aset menjadi konsep sebagai pemakai dari aset yang diamanahkan (rasionalisasi) (Tickner \& Button, 2021).

Banyak dari pelaku tindakan fraud mengetahui dan menyadari tindakan yang dilakukan itu merupakan tindakan yang illegal, namun para pelaku fraud memunculkan pemikiran bahwa tindakan yang dilakukan tersebut merupakan suatu hal yang wajar. Maka, Cressey mengelompokkan tiga faktor utama penyebab terjadinya fraud, yakni tekanan (pressure), peluang (opportunity), dan rasionalisasi (rationalization).

\section{Pengaruh Kinerja Keuangan Daerah terhadap Korupsi pada Pemerintahan Daerah}

Penilaian Kinerja Keuangan Daerah dilakukan untuk menilai kemampuan pemerintah daerah dalam mengelola keuangan wilayah daerahnya. Kinerja Keuangan Daerah diukur menggunakan rasio-rasio keuangan berdasarkan realisasi dari APBD. Belanja daerah dilakukan untuk 
memberikan pelayanan dan kesejahteraan kepada masyarakat. Dana dari belanja daerah berasal dari Pendapatan daerah.

Suhardjanto et al (2020) menemukan kinerja keuangan daerah berpengaruh negatif terhadap korupsi. Semakin baik nilai kinerja keuangan pemerintah daerah maka semakin kecil tingkat korupsi. Sebaliknya, semakin buruk kinerja keuangan pemerintah daerah maka semakin besar tingkat korupsinya.

H1: Kinerja keuangan daerah berpengaruh negatif terhadap korupsi pada pemerintah daerah di Indonesia

\section{Pengaruh Kinerja Keuangan Daerah terhadap Korupsi pada Pemerintahan Daerah}

Penilaian Kinerja Keuangan Daerah dilakukan untuk menilai kemampuan pemerintah daerah dalam mengelola keuangan wilayah daerahnya. Kinerja Keuangan Daerah diukur menggunakan rasio-rasio keuangan berdasarkan realisasi dari APBD. Belanja daerah dilakukan untuk memberikan pelayanan dan kesejahteraan kepada masyarakat. Dana dari belanja daerah berasal dari Pendapatan daerah.

Suhardjanto et al (2020) menemukan kinerja keuangan daerah berpengaruh negatif terhadap korupsi. Semakin baik nilai kinerja keuangan pemerintah daerah maka semakin kecil tingkat korupsi. Sebaliknya, semakin buruk kinerja keuangan pemerintah daerah maka semakin besar tingkat korupsinya.

H1: Kinerja keuangan daerah berpengaruh negatif terhadap korupsi pada pemerintah daerah di Indonesia

\section{Pengaruh Pendapatan Daerah terhadap Korupsi di Pemerintahan Daerah}

Penelitian Maria et al., (2018) menemukan bahwa Pendapatan daerah adalah faktor yang menekan adanya fraud pada pemerintah daerah. Saat Pendapatan daerah tinggi namun realisasi belanjanya rendah maka memungkinkan pemerintah daerah mengalami surplus. Kondisi surplus menunjukkan bahwa pemerintah daerah memiliki anggaran yang tidak terserap sehingga pelayanan kepada masyarakat menjadi kurang optimal. Selain itu, kondisi surplus juga dapat mengganggu program-program pemerintah daerah pada periode berikutnya karena pemerintah daerah yang memiliki surplus memiliki kewajiban untuk mengembalikan dana tersebut ke kas negara dan sebagai konsekuensinya maka pengajuan anggaran periode selanjutnya tidak boleh melebihi realisasinya, sebagaimana yang diatur dalam Perdirjen Perbendaharaan No. 1 Tahun 2013. Sehingga, kondisi tersebut berdampak pada pemerintah daerah untuk melakukan korupsi dan membelanjakan surplus dengan membuat kebijakan digunakan untuk keuntungan pribadi atau untuk kelompok tertentu di lingkungan pemerintah daerah, dan bukan untuk preferensi publik.

H2: Pendapatan daerah berpengaruh positif terhadap korupsi pada pemerintah daerah di Indonesia

\section{Pengaruh Belanja Modal Daerah terhadap korupsi di Pemerintahan Daerah}

Mauro (1998) dalam Maria et al (2019) menemukan pelaku korupsi pada pemerintahan daerah bisa dengan mudah melakukan dan menyembunyikan tindakan korupsi pada kegiatan belanja modal. Pengusaha sering kali mempengaruhi pejabat daerah dan/atau kepala daerah untuk ikut campur dalam proses pengadaan belanja modal agar tender dimenangkan oleh pengusaha tersebut kemudian harga barang/jasa dinaikkan atau biasa disebut mark up, dan selisihnya dibagi-bagikan. Kondisi tersebut dinilai sebagai peluang untuk melakukan korupsi berbekal informasi dan keahlian yang dimiliki tanpa diketahui orang lain.

Penelitian oleh Maria et al., (2019) dan Rahmasari \& Setiawan (2021) menemukan bahwa belanja modal berpengaruh positif terhadap peluang untuk melakukan korupsi pada pemerintah daerah. Peluang untuk melakukan korupsi semakin tinggi jika pemerintah daerah memiliki dana untuk belanja modal yang besar.

H3: Belanja Modal Daerah berpengaruh positif terhadap korupsi pada pemerintah daerah di Indonesia 


\section{Pengaruh Kemampuan Audit Internal Terhadap Korupsi Pada Pemerintahan Daerah}

Penilaian Pengendalian internal yang lemah pada pemerintah bisa menimbulkan pemikiran dari pegawai pemerintah bahwa terdapat peluang untuk melakukan korupsi. Pengendalian internal yang tidak efektif bisa menyebabkan peluang bagi pelaku untuk melakukan tindakan korupsi, menyembunyikannya, dan menghindari adanya temuan dan hukumannya (Muhtar et al., 2018). Untuk mencegah hal tersebut maka pengawasan pada pemerintah daerah sangat penting untuk memastikan pengendalian internal berjalan dengan efektif, sehingga bisa mencegah terjadinya korupsi. Pengawasan pada pemerintah daerah dilakukan oleh Inspektorat Daerah dan BPKP sebagai audit internal pemerintah, yang dapat melaporkan adanya peluang untuk melakukan korupsi sehingga dari laporan tersebut pemerintah dapat mencegah terjadinya korupsi dengan menghilangkan peluang tersebut.

Muhtar et al (2018) dan Rahmasari \& Setiawan (2021) menemukan kapabilitas audit internal berpengaruh negatif terhadap korupsi.

H4: Kemampuan Audit Internal berpengaruh negative terhadap korupsi pada pemerintah daerah di Indonesia

\section{Pengaruh Opini Audit terhadap Korupsi}

BPK yang dalam hal ini menjadi auditor adalah instansi yang bertugas mencegah adanya kecurangan dalam pelaporan keuangan. Opini terhadap laporan keuangan seharusnya menunjukkan bahwa informasi dalam laporan keuangan benar dan reliabel. Terjadinya penyimpangan dalam bentuk korupsi pada suatu instansi pemerintah menunjukkan bahwa data keuangan pada laporan keuangan instansi tersebut tidak reliabel.

Terdapat empat opini yang dikeluarkan oleh BPK, yaitu WTP, WDP, TW, dan TMP. Laporan keuangan yang beropini WTP berarti telah disusun sesuai SAP, melalui sistem dan prosedur yang baik termasuk pelaksanaan kegiatan dan pengelolaan keuangan, pencatatan, dan penatausahaan bukti-bukti transaksi. Disamping itu, dengan opini WTP, kehandalan SPI entitas yang bersangkutan telah berjalan dengan baik sehingga tujuan SPI telah tercapai berupa efektivitas dan efisiensi pelaksanaan kegiatan dan pengelolaan keuangan, pengamanan aset serta ketaatan terhadap ketentuan perundangan. Hal ini mempersempit peluang bagi pegawai pemerintahan untuk melakukan korupsi (Rahmatullah, 2020).

Penelitian oleh Hikam et al., (2020) menunjukan opini audit berpengaruh negatif dan signifikan terhadap fraud pada pemerintah daerah. Semakin baik nilai opini audit yang diberikan maka semakin rendah fraud yang dilakukan, dan begitu juga sebaliknya. Semakin buruk opini audit yang diberikan maka semakin tinggi fraud yang dilakukan.

H5: Opini audit berpengaruh negatif terhadap korupsi pada pemerintah daerah di Indonesia

\section{Belanja Pegawai Daerah terhadap Korupsi}

Pegawai menerima gaji atau kompensasi atas pekerjaan yang telah dilakukan. Ketidakpuasan terhadap kebijakan pemerintah mengenai pengupahan merupakan salah satu bentuk rasionalisasi untuk membenarkan tindakan korupsi yang dilakukan. Pegawai pemerintahan yang bergaji rendah dengan tanggung jawab dan beban kerja yang besar akan menuntut gaji yang lebih secara informal bahkan dengan tindakan yang ilegal. Pegawai pemerintahan tidak bisa meminta kenaikan gaji secara terang-terangan karena gaji pegawai pemerintahan telah diatur dalam undang-undang berdasarkan golongan dan lama masa kerja. Karena hal tersebut maka pegawai pemerintahan yang tidak puas dengan gajinya karena merasa beban kerjanya tidak sebanding dengan gajinya bisa memicu pegawai untuk melakukan tindakan korupsi. Sebaliknya, tingkat gaji yang lebih tinggi membuat inspirasi untuk tidak melakukan praktik korupsi karena pegawai merasa puas dengan gaji ya lebih tinggi.

Muhtar et al (2018) menemukan belanja pegawai daerah berpengaruh negatif terhadap korupsi.

H6: Belanja pegawai daerah berpengaruh negatif terhadap korupsi pada pemerintah daerah di Indonesia 
Owner: Riset \& Jurnal Akuntansi

e-ISSN : 2548-9224 |p-ISSN : 2548-7507

Volume 6 Nomor 1, Januari 2022

\section{Kerangka Pemikiran}

Kerangka penelitian menggambarkan metode pengujian hipotesis serta hubungan masingmasing variabel, dan hal tersebut ditampilkan pada gambar 1.

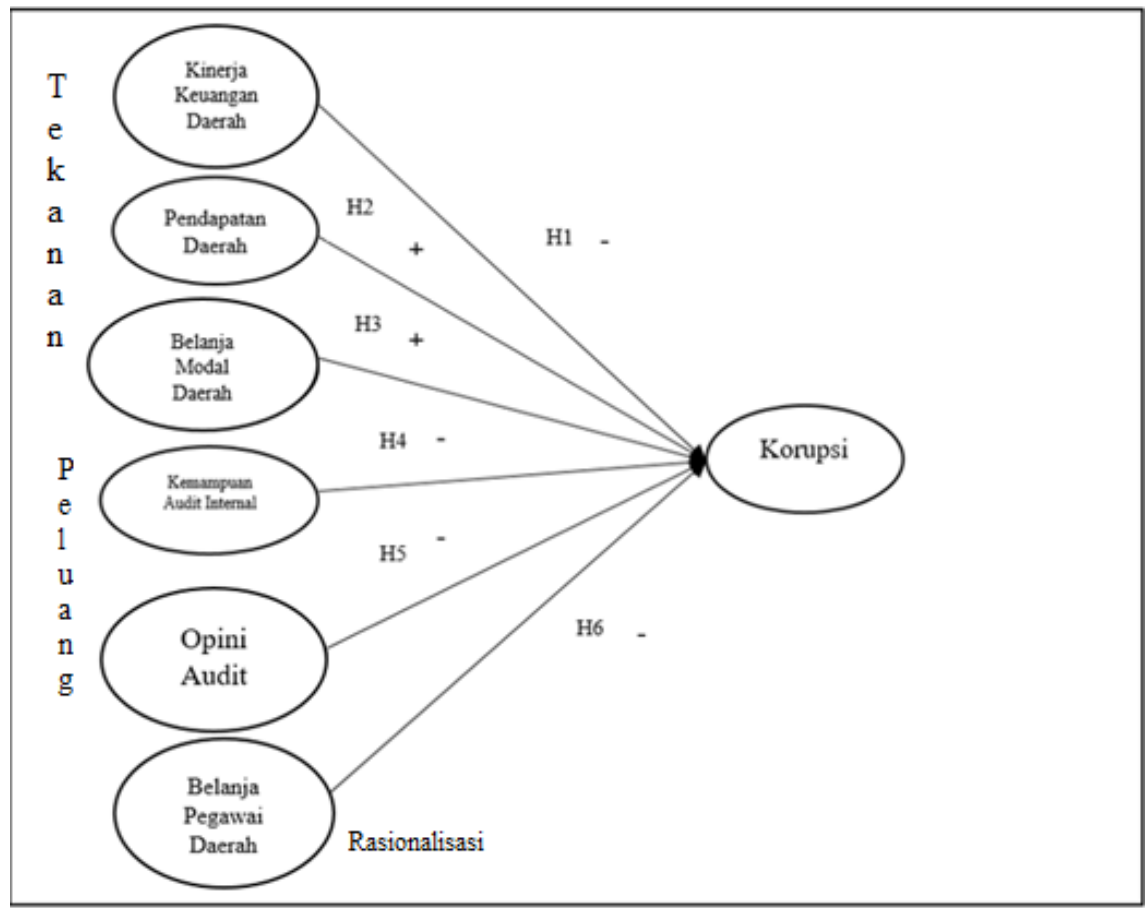

Gambar 1. Kerangka Penelitian

Sumber: (Hikam et al., 2020; Isnadiva \& Haryanto, 2021; Maria \&

Gudono, 2017; Maria et al., 2018, 2019; Muhtar et al., 2018; Nuruddinia

\& Rahmawati, 2021; Rahayuningtyas \& Setyaningrum, 2017; Rahmasari

\& Setiawan, 2021)

\section{METODE}

\section{Variabel Penelitian dan Definisi Operasional Variabel}

\section{Variabel Dependen}

\section{Korupsi}

Korupsi adalah tindakan memperkaya diri sendiri atau orang lain atau suatu instansi yang bisa membuat rugi ekonomi dan keuangan negara (Rahayuningtyas \& Setyaningrum, 2017). Korupsi diukur dengan menggunakan skala nominal variabel dummy yakni dengan memberikan angka 0 untuk daerah yang tidak terdapat kasus korupsi dan angka 1 untuk daerah yang terdapat kasus korupsi dan telah mencapai putusan pada pengadilan tingkat pertama masing-masing daerah, seperti pada penelitian Maria \& Gudono (2017), Nuruddinia \& Rahmawati (2021), dan Maria \& Halim (2021). Data mengenai daerah yang memiliki kasus korupsi diperoleh melalui website direktori putusan Mahkamah Agung. Pada penelitian ini variabel korupsi dilambangkan dengan KOR.

\section{Variabel Independen}

\section{Kinerja Keuangan Daerah}

Kemampuan pemerintah daerah menggunakan anggaran jika dibandingkan dengan Pendapatan (Maria et al., 2018). Penghitungan kinerja keuangan daerah dengan rumus seperti berikut:

\section{Pendapatan Daerah}

$$
\text { Kinerja Keuangan Daerah }=\frac{\text { Pendapatan Daerah }- \text { Belanja Daerah }}{\text { Pendapatan Daerah }}
$$

Kemampuan daerah untuk mengolah potensi dari daerahnya (Maria et al, 2018). Pendapatan daerah diukur dengan rumus sebagai berikut: 


\section{Kemampuan Audit Internal}

$$
\text { Pendapatan Daerah }=\ln (P A D)
$$

Kemampuan auditor dalam melaksanakan tugas pengawasan yang meliputi unsur kapasitas, kewenangan, dan kompetensi. Kemampuan audit internal diukur menggunakan penilaian Kapabilitas APIP yang berbasis IACM yang dinilai menggunakan skala ordinal 1 sampai 5, dimana: $1=$ initial, $2=$ infrastructure, $3=$ integrated, $4=$ managed, dan $5=$ optimizing Kinerja Opini Audit

Kemampuan pemerintah daerah menggunakan anggaran jika dibandingkan dengan Pendapatan (Maria et al., 2018). Penghitungan kinerja keuangan daerah dengan rumus seperti berikut:

$$
\text { Kinerja Keuangan Daerah }=\frac{\text { Pendapatan Daerah }- \text { Belanja Daerah }}{\text { Pendapatan Daerah }}
$$

\section{Kinerja Keuangan Daerah}

Kemampuan pemerintah daerah menggunakan anggaran jika dibandingkan dengan Pendapatan (Maria et al., 2018). Penghitungan kinerja keuangan daerah dengan rumus seperti berikut:

\section{Kinerja Keuangan Daerah}

$$
\text { Kinerja Keuangan Daerah }=\frac{\text { Pendapatan Daerah }- \text { Belanja Daerah }}{\text { Pendapatan Daerah }}
$$

Kemampuan pemerintah daerah menggunakan anggaran jika dibandingkan dengan Pendapatan (Maria et al., 2018). Penghitungan kinerja keuangan daerah dengan rumus seperti berikut:

\section{Populasi dan Sampel}

$$
\text { Kinerja Keuangan Daerah }=\frac{\text { Pendapatan Daerah }- \text { Belanja Daerah }}{\text { Pendapatan Daerah }}
$$

Populasi pada penelitian ini yaitu pemerintah daerah tingkat kabupaten/kota dan daerah Provinsi pada Provinsi Jawa Tengah yang berjumlah 35 pada tahun anggaran 2015 - 2019. Sistematika pengambilan sampel memakai purposive sampling. Sampel pada penelitian ini yaitu pemerintah daerah tingkat kabupaten/kota pada Provinsi Jawa Tengah tahun anggaran 2015 - 2019 yang terdapat kasus korupsi dan telah diputuskan pengadilan tingkat pertama masing-masing daerah, telah diaudit oleh BPK, memiliki penilaian Kapabilitas APIP oleh BPKP, dan memiliki kelengkapan LKPD yang meliputi rincian realisasi pendapatan dan belanja daerah. Data yang digunakan merupakan data sekunder, yaitu dari laporan keuangan wilayah daerah dari BPS, opini audit dari BPK, putusan Mahkamah Agung, dan LKJIP BPKP yang diperoleh melalui website masing-masing instansi.

\section{Metode Analisis dan Uji Hipotesis}

Metode analisa data pada penelitian ini menggunakan analisa statistik deskriptif dan pengujian hipotesis menggunakan analisa regresi logistik dengan program IBM SPSS Statistics versi 26. Adapun persamaan regresi logistic yang digunakan dalam penelitian ini adalah:

$$
K O R=B 0+B 1 K K D+B 2 P A D+B 3 B M+B 4 K A I+B 5 O A+B 6 B P+e
$$

\footnotetext{
Dimana:

B0 = Konstanta

$\mathrm{B}=$ Koefisien Variabel

KOR $=$ Korupsi

$\mathrm{KKD}=$ Kinerja Keuangan Daerah

$\mathrm{PAD}=$ Pendapatan Daerah

$\mathrm{BM}=$ Belanja Modal

$\mathrm{KAI}=$ Kemampuan Audit Internal

$\mathrm{OA}=$ Opini Audit
} 
$\mathrm{BP}=$ Belanja Pegawai Daerah

$\mathrm{e}=$ Error

HASIL

Statistik Deskriptif

Tabel 1. Statistik Deskriptif

\begin{tabular}{|c|c|c|c|c|c|}
\hline & $\mathbf{N}$ & Minimum & Maximum & Mean & Std. Deviation \\
\hline KOR & 145 & 0 & 1 & .46 & .500 \\
\hline KKD & 145 & -.187 & .531 & -.02007 & .087279 \\
\hline PAD & 145 & 18.214 & 21.775 & 19.54883 & .535401 \\
\hline BM & 145 & 18.537 & 21.713 & 19.65365 & .468662 \\
\hline KAI & 145 & 1 & 3 & 2.18 & .796 \\
\hline OA & 145 & 0 & 1 & .86 & .346 \\
\hline BP & 145 & .340 & 1.144 & .47375 & .094934 \\
\hline
\end{tabular}

Sumber: Data yang diolah

Berdasarkan hasil perhitungan pada tabel diatas dapat dianalisis sebagai berikut:

a) Variabel Korupsi (KOR) memiliki nilai rara-rata senilai 0,46, dengan nilai terkecil sebesar 0 dan nilai terbesar sebesar 1 . Variabel korupsi memiliki persebaran data atau standar deviasi sebesar 0,500.

b) Variabel Pendapatan Daerah (PAD) memiliki nilai rata-rata senilai 19,54883, dengan nilai terkecil sebesar 18,214 dan nilai terbesar sebesar 21,775. Variabel Pendapatan daerah memiliki persebaran data sebesar 0,535401 .

c) Variabel Belanja Modal Daerah (BM) memiliki nilai rata-rata senilai 19,65365, dengan nilai terkecil 18,537 dan nilai terbesar 21,713. Variabel belanja modal daerah memiliki persebaran data sebesar 0,468662 .

d) Variabel Kemampuan Audit Internal (KAI) memiliki nilai rata-rata senilai 2,18, dengan nilai terkecil 1 dan nilai terbesar 3. Variabel kemampuan audit internal memiliki standar deviasi sebesar 0,796.

e) Variabel Opini Audit (OA) memiliki nilai rata-rata senilai 0,86, dengan nilai terkecil sebesar 0 dan nilai terbesar sebesar 1 . Variabel opini audit mempunyai persebaran data sebesar 0,346.

f) Variabel Belanja Pegawai Daerah (BP) memiliki nilai rata-rata senilai 0,47375, dengan nilai terkecil sebesar 0,340 dan nilai terbesar sebesar 1,144. Variabel belanja pegawai daerah memiliki persebaran data sebesar 0,094934.

\section{Overall Fit Model}

Overal fit model dihitung dengan cara membandingkan nilai antar $-2 \operatorname{LogL}$ pada model awal atau block 0 dengan -2LogL pada model akhir atau block 1 .

Tabel 2. Iteration History Block 0

\begin{tabular}{|c|l|r|r|}
\hline \multicolumn{2}{|c|}{ Iteration } & \multicolumn{1}{c|}{$\begin{array}{c}-2 \text { Log } \\
\text { likelihood }\end{array}$} & $\begin{array}{c}\text { Coefficients } \\
\text { Constant }\end{array}$ \\
\hline \multirow{2}{*}{ Step 0 } & 1 & 199.846 & -.179 \\
\cline { 2 - 4 } & 2 & 199.846 & -.180 \\
\hline
\end{tabular}

Sumber: Data yang diolah

Tabel 3. Iteration History Block 1 
Owner: Riset \& Jurnal Akuntansi

e-ISSN : 2548-9224 | p-ISSN : 2548-7507

Volume 6 Nomor 1, Januari 2022

\begin{tabular}{|c|c|c|c|c|c|c|c|c|c|}
\hline \multirow{2}{*}{\multicolumn{2}{|c|}{ Iteration }} & \multirow{2}{*}{$\begin{array}{c}-2 \text { Log } \\
\text { likelihood }\end{array}$} & \multicolumn{7}{|c|}{ Coefficients } \\
\hline & & & Constant & KKD & PAD & BM & KAI & $\mathbf{O A}$ & BP \\
\hline \multirow[t]{5}{*}{ Step 1} & 1 & 179.059 & -14.745 & .319 & -.554 & 1.265 & -.241 & -.878 & 3.841 \\
\hline & 2 & 177.454 & -21.618 & 1.427 & -.654 & 1.682 & -.253 & -1.177 & 5.894 \\
\hline & 3 & 177.404 & -22.980 & 1.789 & -.675 & 1.766 & -.256 & -1.236 & 6.293 \\
\hline & 4 & 177.404 & -23.024 & 1.806 & -.676 & 1.769 & -.256 & -1.238 & 6.305 \\
\hline & 5 & 177.404 & -23.024 & 1.806 & -.676 & 1.769 & -.256 & -1.238 & 6.305 \\
\hline
\end{tabular}

Sumber: Data yang diolah

Tabel 2 merupakan model awal atau block 0 yaitu model sebelum variabel independen dimasukan. Nilai -2LogL pada model awal atau block 0 adalah sebesar 199,846. Hal ini menunjukkan bahwa hipotesis nol ditolak, yang artinya hanya konstanta saja yang fit dengan data.

Sedangkan pada tabel 3 merupakan model akhir block 1 yaitu model setelah variabel independen dimasukkan. Nilai -2LogL pada model akhir atau block 1 adalah sebesar 177,404. Dari hasil kedua model, terjadi penurunan nilai -2LogL dari model awal ke model akhir sebesar 22,442. Nilai -2LogL yang berkurang berarti ditambahkannya variabel independen kedalam model bisa memperbaiki model fit dan menunjukan model regresi yang baik atau model yang di hipotesiskan fit dengan data, maka dengan demikian hipotesis nol diterima.

\section{Koefisien Determinasi}

Tabel 4. Model Summary

\begin{tabular}{|l|c|c|c|}
\hline Step & $\begin{array}{c}-\mathbf{2} \text { Log } \\
\text { likelihood }\end{array}$ & $\begin{array}{c}\text { Cox \& Snell } \\
\text { R Square }\end{array}$ & $\begin{array}{c}\text { Nagelkerke } \\
\text { R Square }\end{array}$ \\
\hline 1 & 177.404 & .143 & .192 \\
\hline
\end{tabular}

Sumber: Data yang diolah

Pada tabel 4 di atas menunjukkan nilai Nagelkerke $\mathrm{R}^{2}$ senilai 0,192 . Hal ini berarti variabel dependen korupsi dijelaskan oleh variabel-variabel independen kinerja keuangan daerah, Pendapatan daerah, belanja modal daerah, kemampuan audit internal, opini audit, dan belanja pegawai daerah sebesar 0,192 atau $19,2 \%$. Sisanya sebesar $80,8 \%$ dijelaskan oleh variabel lain di luar model penelitian ini.

\section{Hosmer and Lemeshow's Goodness of Fit Test}

Tabel 5. Hosmer and Lemeshow's Goodness of Fit Test

\begin{tabular}{|l|r|c|c|}
\hline Step & Chi-square & df & Sig. \\
\hline 1 & 5.197 & 8 & .736 \\
\hline
\end{tabular}

Sumber: Data yang diolah

Berdasarkan tabel 5, hasil uji Hosmer and Lemeshow goodneess of fit Test memiliki nilai $\chi^{2}$ sebesar 5,197 dengan nilai signifikansinya sebesar 0,736. Nilai signifikansi yang diperoleh $>$ dari 0,05 , sehingga hipotesis nol diterima. 
Tabel 6. Regresi Logistik

\begin{tabular}{|c|c|c|c|c|c|c|c|}
\hline & & B & S.E. & Wald & df & Sig. & $\operatorname{Exp}(B)$ \\
\hline Step & KKD & 1.806 & 3.149 & .329 & 1 & .566 & 6.085 \\
\hline 1 & PAD & -.676 & .470 & 2.068 & 1 & .150 & .509 \\
\hline & $\mathrm{BM}$ & 1.769 & .610 & 8.420 & 1 & .004 & 5.866 \\
\hline & KAI & -.256 & .273 & .878 & 1 & .349 & .774 \\
\hline & $\mathrm{OA}$ & -1.238 & .623 & 3.955 & 1 & .047 & .290 \\
\hline & $\mathrm{BP}$ & 6.305 & 3.040 & 4.302 & 1 & .038 & 547.416 \\
\hline & Constant & -23.024 & 10.926 & 4.441 & 1 & .035 & .000 \\
\hline
\end{tabular}

Sumber: Data yang diolah berikut:

Berdasarkan tabel di atas, model persamaan regresi logistik pada penelitian ini yaitu sebagai

$$
\begin{gathered}
K O R=-23,024+1,806 K K D-0,676 P A D+1,769 B M-0,256 K A I-1,2380 A+6,305 B P \\
+e
\end{gathered}
$$

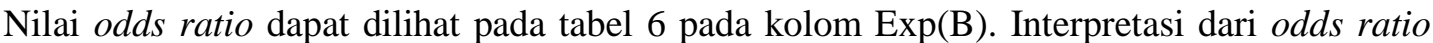
adalah sebagai berikut:

1. Jika Kinerja Keuangan Daerah bertambah 1 maka kecenderungan korupsi menjadi 6,085 kali lipat.

2. Jika Pendapatan daerah bertambah 1 maka kecenderungan korupsi menjadi 0,509 kali lipat.

3. Jika belanja modal daerah bertambah 1 maka kecenderungan korupsi menjadi 5,866 kali lipat.

4. Jika kemampuan audit internal bertambah 1 maka kecenderungan korupsi menjadi 0,774 kali lipat.

5. Jika opini audit bertambah 1 maka kecenderungan korupsi menjadi 0,290 kali lipat.

6. Jika belanja pegawai daerah bertambah 1 maka kecenderungan korupsi menjadi 547,416 kali lipat.

PEMBAHASAN

\begin{tabular}{|c|c|c|c|}
\hline Hipotesis & Hubungan & Hasil & Keterangan \\
\hline $\mathrm{H} 1$ & $\begin{array}{l}\text { Kinerja keuangan daerah berpengaruh } \\
\text { negatif terhadap korupsi }\end{array}$ & $\begin{array}{l}\text { Tidak } \\
\text { berpengaruh }\end{array}$ & Tidak terbukti \\
\hline $\mathrm{H} 2$ & $\begin{array}{l}\text { Pendapatan daerah berpengaruh positif } \\
\text { terhadap korupsi }\end{array}$ & $\begin{array}{l}\text { Tidak } \\
\text { berpengaruh }\end{array}$ & Tidak terbukti \\
\hline $\mathrm{H} 3$ & $\begin{array}{l}\text { Belanja modal daerah berpengaruh positif } \\
\text { terhadap korupsi }\end{array}$ & $\begin{array}{l}\text { Berpengaruh } \\
\text { positif }\end{array}$ & Terbukti \\
\hline $\mathrm{H} 4$ & $\begin{array}{l}\text { Kemampuan audit internal berpengaruh } \\
\text { negatif terhadap korupsi }\end{array}$ & $\begin{array}{l}\text { Tidak } \\
\text { berpengaruh }\end{array}$ & Tidak terbukti \\
\hline H5 & $\begin{array}{l}\text { Opini audit berpengaruh negatif terhadap } \\
\text { korupsi }\end{array}$ & $\begin{array}{l}\text { Berpengaruh } \\
\text { negatif }\end{array}$ & Terbukti \\
\hline H6 & $\begin{array}{l}\text { Belanja pegawai daerah berpengaruh } \\
\text { negatif terhadap }\end{array}$ & $\begin{array}{l}\text { Berpengaruh } \\
\text { positif }\end{array}$ & Tidak terbukti \\
\hline
\end{tabular}

Tabel 7 . Uji Hipotesis

Sumber: Disusun oleh penulis.

Berdasarkan tabel diatas, pengujian hipotesis pertama yang menunjukkan bahwa hipotesis ditolak. Hal ini mengacu pada hasil uji $\mathrm{T}$ yang menunjukkan bahwa Kinerja keuangan daerah berpengaruh negatif terhadap korupsi yang memiliki koefisien regresi positif sebesar 1,806 dengan tingkat signifikansi sebesar 0,566 yang lebih besar dari 0,05. Hasil penelitian ini sesuai dengan penelitian oleh Maria et al., (2018) yang hasilnya Kinerja Keuangan Daerah tidak berpengaruh terhadap korupsi. Kinerja keuangan daerah tidak bisa menjelaskan korupsi yang 
terjadi di pemerintahan daerah. Berdasarkan hasil pada penelitian ini, kinerja keuangan daerah di Jawa Tengah masih belum cukup efisien sehingga bisa menimbulkan terjadinya korupsi.

Pengujian hipotesis kedua menunjukkan bahwa hipotesis kedua ditolak. Hal ini mengacu pada hasil uji T yang menunjukkan bahwa Pendapatan daerah berpengaruh positif terhadap korupsi yang menunjukkan variabel Pendapatan daerah memiliki koefisien regresi negatif sebesar -0,676 dengan tingkat signifikansi sebesar 0,150 yang lebih besar dari 0,05 . Hasil penelitian ini sesuai dengan penelitian dari Muhtar et al., (2018) bahwa Pendapatan daerah tidak berpengaruh terhadap korupsi di pemerintahan daerah. Kemampuan pemerintah daerah dalam mengelola Pendapatan daerah dari potensi daerahnya untuk pelaksanaan kegiatan pemerintah tidak mempengaruhi pegawai pemerintahan dalam melakukan tindakan korupsi. Selain itu, jika pemerintah daerah mengalami surplus, sisa Pendapatan yang tidak digunakan akan ditransfer ke pemerintah pusat. Berdasarkan hasil pada penelitian ini, pendapatan daerah Kabupaten/Kota di Jawa Tengah memiliki rentan pendapatan yang bervariasi sehingga tidak bisa menjadi tolak ukur terhadap terjadinya korupsi pada pemerintah daerah di Jawa Tengah.

Pengujian hipotesis ketiga menunjukkan bahwa hipotesis kedua diterima. Hal ini mengacu pada hasil uji $\mathrm{T}$ yang menunjukkan bahwa Belanja modal daerah berpengaruh positif terhadap korupsi yang menunjukkan variabel belanja modal daerah memiliki koefisien regresi positif sebesar 1,769 dengan tingkat signifikansi sebesar 0,004 yang lebih kecil dari 0,05. Hasil penelitian ini sejalan dengan hasil penelitian Maria et al., (2019) dan Rahmasari \& Setiawan (2021) yang menemukan belanja modal daerah berpengaruh positif terhadap korupsi pada pemerintahan daerah. Mitra terkait dalam belanja modal seperti pengusaha bisa mempengaruhi kepada daerah atau pejabat daerah terkait dalam proses pengadaan belanja modal daerah. Kepada daerah atau pejabat daerah terkait bisa mengambil peluang ini untuk melakukan tindakan korupsi karena memiliki kewenangan dalam proses pengadaan belanja modal. Belanja modal daerah merupakan kegiatan yang rutin dilakukan pemerintah daerah karena sudah disusun anggarannya tiap periode, sehingga peluang untuk melakukan tindakan korupsi pada proses pengadaan belanja modal ini bisa saja terus dilakukan. Korupsi yang melibatkan banyak orang dalam proses pengadaan belanja modal membuat korupsi sulit dideteksi oleh auditor.

Pengujian hipotesis keempat menunjukkan bahwa hipotesis ditolak. Hal ini mengacu pada hasil uji T yang menunjukkan bahwa Kemampuan audit internal berpengaruh negatif terhadap korupsi yang menunjukkan variabel kemampuan audit internal memiliki koefisien regresi negatif sebesar -0,256 dengan tingkat signifikansi sebesar 0,346 yang lebih besar dari 0,05. Hasil penelitian ini sejalan dengan temuan Muhtar et al., (2018) dan Rahmasari dan Setiawan (2021) bahwa kemampuan audit internal tidak berpengaruh terhadap korupsi pada pemerintahan daerah. Kemampuan audit internal mencerminkan sistem pengendalian internal untuk mencegah peluang terjadinya korupsi. Auditor tidak bisa melaporkan kasus korupsi yang sedang terjadi tetapi bisa melaporkan adanya indikasi peluang untuk melakukan korupsi, sehingga membutuhkan waktu sampai kasus korupsi benar-benar terungkap. Hal tersebut dikarenakan fungsi utama auditor bukan sebagai pengontrol tetapi sebagai mitra strategis bagi pemerintah daerah dalam pengelolaan keuangan, tata kelola, manajemen risiko, pengendalian internal, dan memastikan efisiensi, efektivitas, dan nilai ekonomi program, tidak hanya pada pencegahan tindakan korupsi saja.

Pengujian hipotesis kelima menunjukkan bahwa hipotesis kelima diterima. Hal ini mengacu pada hasil uji $\mathrm{T}$ yang menunjukkan bahwa Opini audit berpengaruh negatif terhadap korupsi yang menunjukkan bahwa variabel opini audit memiliki koefisien regresi negatif sebesar -1,238 dengan tingkat signifikansi sebesar 0,047 yang lebih kecil dari 0,05 . Hasil penelitian ini sesuai dengan temuan Hikam et al., (2020) yang menemukan opini audit berpengaruh negatif terhadap korupsi. Dari hasil tersebut memperlihatkan bahwa BPK telah efektif mencegah peluang tindakan korupsi melalui pemberian rekomendasi perbaikan dan sanksi atas setiap temuan kelemahan pengendalian atau temuan ketidaktaatan terhadap aturan yang berlaku. Berdasarkan rekomendasi tersebut, BPK juga memantau proses perbaikan yang dilakukan oleh pemerintah daerah sehingga dapat membantu pemerintah daerah dalam mewujudkan tata kelola keuangan wilayah daerah yang transparan dan akuntabel. Tren opini audit yang dilakukan oleh BPK atas pemeriksaan LKPD juga memperlihatkan peningkatan yang menunjukkan bahwa LKPD masing-masing daerah telah melaporkan laporan keuangannya dengan tepat dan sesuai dengan standar akuntansi pemerintah 
yang telah ditetapkan, sehingga semakin sedikit adanya temuan kecurangan dan kesalahan penyajian laporan keuangan yang mengarah kepada tindakan korupsi.

Pengujian hipotesis kelima menunjukkan bahwa hipotesis keenam diterima. Hal ini mengacu pada hasil uji $\mathrm{T}$ yang menunjukkan bahwa Belanja pegawai daerah berpengaruh negatif terhadap korupsi yang menunjukkan variabel belanja pegawai daerah memiliki koefisien regresi positif sebesar 6,305 dengan tingkat signifikansi sebesar 0,038 yang lebih kecil dari 0,05. Hasil penelitian ini sesuai dengan penelitian oleh Rahayuningtyas dan Setyaningrum (2017) yang menemukan tingkat gaji pegawai pemerintahan berpengaruh terhadap korupsi di pemerintahan daerah.

Korupsi disebabkan oleh sifat rakus, meski gaji yang diterima besar, pegawai pemerintahan tetap memiliki motivasi untuk meningkatkan hartanya melalui perbuatan korupsi. Terbukti beberapa kepala daerah dan anggota dewan legislatif yang memiliki gaji yang tinggi tetap saja melakukan tindak korupsi di beberapa daerah. Misalnya pemerintah daerah sedang melakukan program percepatan sehingga pegawai pemerintahan harus bekerja ekstra melebihi jam kerja dan deskripsi pekerjaannya namun tidak diberikan insentif atas pekerjaannya. Hal tersebut bisa memicu untuk merasionalisasikan tindakan untuk melakukan korupsi.

\section{KESIMPULAN}

Berdasarkan hasil penelitian yang telah dilakukan, dapat disimpulkan bahwa variabel Belanja Modal berpengaruh secara positif dan signifikan terhadap korupsi. Variabel Opini Audit berpengaruh secara positif dan signifikan terhadap korupsi, sedangkan variable Kinerja Keuangan Daerah, Pendapatan Daerah, Kemampuan Audit Internal tidak berpengaruh signifikan pada korupsi,

Keterbatasan penelitian ini adalah penelitian ini menggunakan variabel dummy untuk mengukur variabel korupsi berdasarkan putusan kasus korupsi pada pengadilan tingkat pertama masing-masing daerah yang telah tercatat pada Mahkamah Agung (MA). Hal ini tidak bisa mencerminkan secara spesifik berapa kerugian negara akibat korupsi dan jumlah kasus korupsi pada masing-masing daerah. Kemudian, terdapat beberapa pemerintah daerah yang tidak memiliki kelengkapan data yaitu penilaian Kapabilitas APIP sehingga tidak diikutsertakan pada analisa data. Selanjutnya, penelitian ini hanya terbatas pada Pemerintah Daerah tingkat Kabupaten/Kota di Provinsi Jawa Tengah sehingga tidak bisa meneliti faktor-faktor yang menyebabkan korupsi secara keseluruhan.

Saran pada penelitian ini kepada pemerintah daerah untuk melakukan perbaikan dan meningkatkan kualitas serta ketepatan waktu untuk pelaporan penilaian terhadap pemerintah daerah oleh BPKP dan BPK agar informasi yang didapatkan berguna untuk mendeteksi dan mencegah tindakan korupsi. Selanjutnya, pemerintah daerah dapat lebih mengoptimalkan dan produktif dalam menggunakan anggaran belanja modal agar pemerintah daerah dapat memenuhi perbaikan dan pembangunan daerah untuk mencapai tujuan pemerintah daerah yang melayani dan mensejahterakan masyarakat. Terakhir, pemerintah daerah harus memperbaiki dan memastikan manajemen kompensasi pegawai yang diintegrasikan dengan kinerja pegawai dan kepatuhan terhadap peraturan, kode etik, dan moral pegawai.

Saran untuk penelitian mendatang untuk menggunakan rasio-rasio keuangan lain untuk mengukur faktor-faktor yang menyebabkan terjadinya korupsi, menggunakan penilaian-penilaian lain terhadap pemerintah daerah untuk mengukur faktor-faktor yang menyebabkan terjadinya korupsi, menggunakan pengukuran lain untuk mengukur variabel korupsi seperti jumlah kerugian akibat korupsi atau jumlah kasus korupsi yang terjadi, melakukan penelitian mengenai korupsi pada pemerintah daerah di wilayah lain, pemerintah daerah tingkat daerah Provinsi, atau instansi pemerintah lain.

\section{REFERENSI}

Abdullahi, R., \& Mansor, N. (2018). Fraud prevention initiatives in the Nigerian public sector: understanding the relationship of fraud incidences and the elements of fraud triangle theory. Journal of Financial Crime, 25(2).

ACFE. (2014). Fraud Examiners Manual (ACFE, Ed.). Austin. 
ACFE. (2016). Report To the Nations on Occupational Fraud and Abuse: 2016 Global Fraud Study. Association of Certified Fraud Examiners.

ACFE Indonesia. (2020). Survei Fraud Indonesia. Jakarta.

Alamsyah, W. (2021). Kinerja Penindakan Kasus Korupsi Tahun 2020. Jakarta.

Albrecht, W. S., Albrecht, C. O., Albrecht, C. C., \& Zimbelman, M. F. (2012). Fraud Examination (4th ed.). Mason: South-Western.

Arifianto, A. (2001). Corruption in Indonesia: Causes, history, impacts, and possible cures. Braindeis University, 1-26.

Darwis, E. T. R. (2015). Pengaruh belanja modal dan belanja pegawai terhadap tingkat kemandirian keuangan daerah pada Kabupaten/Kota Provinsi Sumatera Barat (studi empiris pada Kabupaten dan Kota Provinsi Sumatera Barat). Jurnal Akuntansi, 3(1).

Fitri, F., \& Nadirsyah. (2020). Pengaruh Tekanan (Pressure), Kesempatan (Opportunity), Rasionalisasi (Rationalization), dan Kapabilitas (Capability) terhadap Kecurangan Pengadaan Barang/Jasa di Pemerintahan Aceh dengan Pemoderasi Budaya Etis Organisasi. Jurnal Ilmiah Mahasiswa Ekonomi Akuntansi (JIMEKA), 5(1), 69-84.

Ghozali, I. (2018). Aplikasi Analisis Multivariate Dengan Program IBM SPSS 25 (9th ed.). Semarang: Badan Penerbit Universitas Diponegoro.

Heriningsih, S., \& Marita. (2013). Pengaruh Opini Audit dan Kinerja Keuangan Pemerintah Daerah terhadap Tingkat Korupsi Pemerintah Daerah (Studi Empiris pada Pemerintah Kabupaten dan Kota di Pulau Jawa). Buletin Ekonomi, 11(1).

Hikam, S., Yunieta, \& Rizkarmen, M. (2020). Audit Opinion and Fraud in Local Government: Case of Indonesia. BISNIS \& BIROKRASI: Jurnal Ilmu Administrasi Dan Organisas, 27(3). https://doi.org/10.20476/jbb.v27i3.12108

Hormati, G. A., \& Pesudo, D. A. A. (2019). Pengaruh Tekanan, Kesempatan, Rasionalisasi, dan Kemampuan terhadap Kecenderungan Aparatur Sipil Negara dalam Melakukan Kecurangan Akuntansi Studi Empiris Satuan Kerja Perangkat Daerah Kabupaten Bolaang Mongondoow Timur. Jurnal Ilmiah Akuntansi Dan Humanika, 9(2), 172-190.

Irman, M., \& Suryati. (2014). The Infulence of Internal Control System Weakness, Incompliance Towards Laws and Regulation, The Previous Year's Audit Opinion and The Age of The Local Government Against Acceptance of an Audit Opinion In The Local Government/Riau Province In 2011-2014. KURS, 2(2), 197-209.

Isnadiva, S. M., \& Haryanto. (2021). Hasil Pemeriksaan dan Kasus Korupsi pada Pemerintah Daerah Studi pada Pemerintah Provinsi di Indonesia Tahun 2015-2018. Jurnal Riset Akuntansi Dan Keuangan, 9(1), 83-100.

LSI. (2021). Tantangan Reformasi Birokrasi: Persepsi Korupsi, Demokrasi, dan Intoleransi di Kalangan PNS. Jakarta.

Mardiasmo. (2018). Akuntansi Sektor Publik. Yogyakarta: Andi.

Maria, E., \& Gudono. (2017). Empirical test of fraud triangle theory on local government (evidence from Indonesia). International Journal of Applied Business and Economic Research, 15(4).

Maria, E., \& Halim, A. (2021). E-government dan korupsi: studi di pemerintah daerah, indonesia dari perspektif teori keagenan. Ekuitas: Jurnal Ekonomi Dan Keuangan, 5(1), 40-58.

Maria, E., Halim, A., \& Suwardi, E. (2018). Eksplorasi Faktor Tekanan untuk Melakukan Fraud di Pemerintah Daerah Indonesia. Jurnal Akuntansi Publik, 1(1).

Maria, E., Halim, A., Suwardi, E., \& Miharjo, S. (2019). Eksplorasi Kesempatan untuk Melakukan Fraud di Pemerintah Daerah, Indonesia. Jurnal Akuntansi Dan Keuangan Indonesia, 16(1).

Muhtar, Sutaryo, \& Sriyanto. (2018). Corruption in Indonesian local government: Study on triangle fraud theory. International Journal of Business and Society, 19(2).

Nuruddinia, M., \& Rahmawati, I. P. (2021). Fraud Triangle dan Korupsi Pada Pemerintah Daerah di Indonesia. Jurnal Riset Akuntansi \& Komputerisasi Akuntansi, 12(1), 110-124.

Olken, B. A. (2007). Monitoring corruption: Evidence from a field experiment in Indonesia. Journal of Political Economy, 115(2), 200-249.

Rahayuningtyas, D. P. A., \& Setyaningrum, D. (2017). Pengaruh Tata Kelola dan E-Government terhadap korupsi. Jurnal Ekonomi Dan Keuangan, 1(4), 431-450. 
Rahmasari, A., \& Setiawan, D. (2021). The Determinants of Frauds in Local Governments. Jurnal Dinamika Akuntansi, 13(1), 37-50.

Rahmatullah. (2020). WTP dan Korupsi.

Sekaran, U., \& Bougie, R. (2016). Research Methods for Business: A Skill-Building Approach (7th ed.). Chichester: John Wiley \& Sons Ltd.

Skousen, C. J., Smith, K. R., \& Wright, C. J. (2009). Detecting and predicting financial statement fraud: The effectiveness of the fraud triangle and SAS No. 99. Advances in Financial Econimics, 13 .

Sugiyono. (2015). Metode Penelitian Pendidikan (Pendekatan Kuantitatif, Kualitatif, dan R\&D). Bandung: Penerbit Alfabeta.

Suhardjanto, D., Djuminah, \& Agustiningsih, S. W. (2020). Regional Financial Performance, Audit Findings, and Corruption Levels in Indonesia. Jurnal Akuntansi Dan Bisnis, 20(1), 81-90.

Suryandadi, N. P. E., Wahyuni, M. A., \& Julianto, I. P. (2019). Pengaruh Tekanan, Kesempatan, Rasionalisasi (Triangle) dan Efektivitas Penerapan Pngendalian Internal terhadap Tindak Kecurangan (Fraud) (Studi PADA LDP Se-Kecamatan Negara). JIMAT (Jurnal Ilmiah Mahasiswa Akuntansi) Universitas Pendidikan Ganesha, 10(1).

Susanto, E. (2019). Korupsi Proyek Jembatan Rp 90 Juta, ASN di Magelang Ditangkap. Retrieved from detikNews website: https://news.detik.com/berita-jawa-tengah/d-4520381/korupsiproyek-jembatan-rp-90-juta-asn-di-magelang-ditangkap

Syaefudin, A. (2021). Seorang ASN Dinas PU Rembang Jadi Tersangka Korupsi Proyek Jalan. Retrieved from detikNews website: https://news.detik.com/berita-jawa-tengah/d5344417/seorang-asn-dinas-pu-rembang-jadi-tersangka-korupsi-proyek-jalan

Tickner, P., \& Button, M. (2021). Deconstructing the Origins of Cressey's Fraud Triangle. Journal of Financial Crimes.

Transparency International. (2021). Corruption Perceptions Index 2020. Berlin.

Wiwoho, L. H. (2016). Korupsi Pembangunan Kolam Retensi, Kepala Dinas Divonis 14 Bulan Penjara. Retrieved from Kompas.com website: https://regional.kompas.com/read/2016/03/10/15151791/Korupsi.Pembangunan.Kolam.Ret ensi.Kepala.Dinas.Divonis.14.Bulan.Penjara 